\title{
Invertebrate bycatch in Patagonian scallop fishing grounds: a study case with data obtained by the On Board Observers Program
}

\author{
Captura incidental de invertebrados en bancos de pesca de vieira patagónica: \\ un caso de estudio con datos obtenidos por el \\ Programa Observadores a Bordo
Mariana Escolar ${ }^{1,2}$, Mariano Diez ${ }^{2,3}$, Daniel Hernández ${ }^{1}$, Ángel Marecos ${ }^{1,2}$, Silvana Campodónico ${ }^{1}$ and Claudia Bremec ${ }^{1,2}$

\author{
${ }^{1}$ Instituto Nacional de Investigación y Desarrollo Pesquero (INIDEP). V.Ocampo 1, B7602HSA Mar del Plata, Argentina \\ ${ }^{2}$ Consejo Nacional de Investigaciones Científicas y Técnicas (CONICET). Rivadavia 1917, C1033AAJ Buenos Aires, Argentina \\ ${ }^{3}$ Centro Austral de Investigaciones Científicas (CADIC-CONICET). Houssay 200, V9410CAB Ushuaia, Argentina \\ marianaescolar@inidep.edu.ar
}

\begin{abstract}
Resumen.- Desde el inicio de la pesquería de vieira patagónica, Zygochlamys patagonica, en el Mar Argentino, en 1996, el Instituto Nacional de Investigación y Desarrollo Pesquero (INIDEP) estableció un Programa de Observadores a Bordo (OBOP). Se analizaron las tendencias generales en la composición de la captura incidental a partir de información provista por OBOP, de capturas y esfuerzo pesquero (219 viajes, 575 muestras), recolectada en cinco bancos de vieira entre $39^{\circ}$ y $44^{\circ} \mathrm{S}$, durante el período 1997-2002. Se encontraron grandes variaciones en la densidad promedio de la captura incidental y la presencia de ocho grupos taxonómicos durante el período estudiado. Echinodermata fue el taxón dominante en la mayoría de los bancos de vieira relevados. Se registraron aumentos en la densidad de equinodermos y gasterópodos, y escasos organismos sésiles en el banco SWSAO, sujeto a esfuerzo pesquero elevado y continuo. En el banco SWTB, menos explotado, se observaron organismos sésiles, cuya densidad disminuyó en el periodo estudiado, y no se registraron cambios en las densidades de equinodermos y gasterópodos. Estos dos últimos grupos, en su mayoría carroñeros y depredadores, se verían favorecidos por un aumento en la disponibilidad de alimento producto de la actividad pesquera (descarte y organismos dañados). Contrariamente los organismos sésiles, sustrato de asentamiento potencial, disminuyeron en densidad en áreas con intensa actividad pesquera. También resaltamos la importancia de esta fuente de datos, que amplía la ventana espacio-temporal de la evaluación anual y optimiza la producción de bases de datos a mayor escala.
\end{abstract}

Palabras clave: Mar Argentino, esfuerzo pesquero, especies no objetivo, pesquería de vieira, Zygochlamys patagonica

\begin{abstract}
Since the beginning of the Patagonian scallop fishery Zygochlamys patagonica, in the Argentine Sea in 1996, an On-Board Observers Program (OBOP) was established at the National Institute of Fishery Research and Development (INIDEP). The general trends of the bycatch composition and biomass were analysed from information on catches and fishing effort (219 trips, 575 samples), collected in five scallop beds between $39^{\circ}$ and $44^{\circ} \mathrm{S}$ during the period $1997-2002$, provided by the OBOP. Large variations in average density of bycatch and the presence of eight taxonomic groups were determined during the study period. Echinodermata was the dominant taxon in most of the scallop beds. Echinoderms and gastropods showed an increase in biomass and sessile organisms were scarce in the SWSAO bed, subjected to high and continuous fishing effort. In the SWTB bed, with the lowest fishing effort, sessile organisms showed a decrease during the study period, while no variations occurred in the case of echinoderms and gastropods. The mentioned groups, mainly scavengers and predators, would be favoured by fishing activity that increased food availability (discards and damaged organisms). Contrarily, potential settlement substrates as sessile organisms, decreased in areas with intensive fishing activities. We stress out the validity of this source of data, which widens the spatio-temporal coverage of the yearly stock assessment cruises and is optimal for producing long-term databases.
\end{abstract}

Keywords: Argentine Sea, fishing effort, non-target species, scallop fishery, Zygochlamys patagonica 


\section{Introduction}

Records of Patagonian scallop, Zygochlamys patagonica (King \& Broderip, 1832) in Argentine waters have been since 1973, when exploitable concentrations were found during an exploratory survey by the fishery research vessel 'Prof. Sieldlecki'. Since then, various assessments have been conducted by research and commercial vessels. Although the commercial potential of this species had been previously stressed ${ }^{1}$ and confirmed by the results of the short experimental fishing survey of the scalloper 'Sea Bay Alpha' during $1989^{2}$, the fishing industry only expressed interest many years later. During 1995, the scalloper 'Erin Bruce' was authorized by the Argentine Government to develop a fishery research program. These investigations lead to the discovery of new beds of Patagonian scallop and a novel fishing activity in the Argentine Sea (Lasta \& Bremec 1998).

It is well documented that bottom otter trawls collect and kill huge amounts of non-target species, mechanically disturb the seabed and can have effects on the structure of benthic communities (Collie et al. 1997, Lindeboom \& de Groot 1998, Hill et al. 1999, Veale et al. 2000). In consequence, since the beginning of the commercial scallop fishery in 1996, an On-Board Observers Program (OBOP) was established at the National Institute of Fishery Research and Development (INIDEP). The main objective of this program is to obtain reliable catch and effort data, as well as to collect biological samples from all species caught by this otter trawl fishery.

This monitoring programme records the abundance and biomass of the main associated invertebrate species (Ciocco et al. 2006) collected while fishing and discarding (the fraction called 'bycatch' in this paper, following Alverson et al. 1994). The fishing gear is claimed to be non-selective, so the observers' information is considered to be a useful tool for analysing the condition of the benthic habitat from information on nontarget organisms.

The aim of this study was to determine general trends of the macroinvertebrate bycatch between 1997 and 2002 in commercial fishing grounds of Patagonian scallops in the Argentine Sea, using information on bycatch and fishing effort provided by the OBOP (INIDEP). In particular, we intended to investigate the response of different faunal groups after five years of relatively lower and higher demersal trawling, and to discuss our results considering the possible effects of fishing activity.

\section{Material and methods}

\section{Study area and fishing data}

The commercial scallop beds studied extend from $39^{\circ}$ to $44^{\circ} \mathrm{S}$ (Fig. 1); they are located within a $20-70 \mathrm{~km}$ wide strip, in a depth range of 81-195 m, along the Argentinian shelf and associated with the shelf break frontal system (Acha et al. 2004). In the period 1997-2002, five factory vessels ('Erin Bruce', 'Mister Big', 'Atlantic Surf I', 'Atlantic Surf II' and 'Atlantic Surf III') completed 219 commercial trips and 52762 fishing hauls. The vessels operated non-selective bottom otter trawls with booms (head and foot rope, between 17 and $22 \mathrm{~m}$ long). Trawling activity was continuous during the day and the duration of a trip ranged between 20 and 40 days. Depending on speed and other technical characteristics, a vessel could complete 40-60 tows day ${ }^{-1}$ net $^{-1}$ (Ciocco et al. 2006).

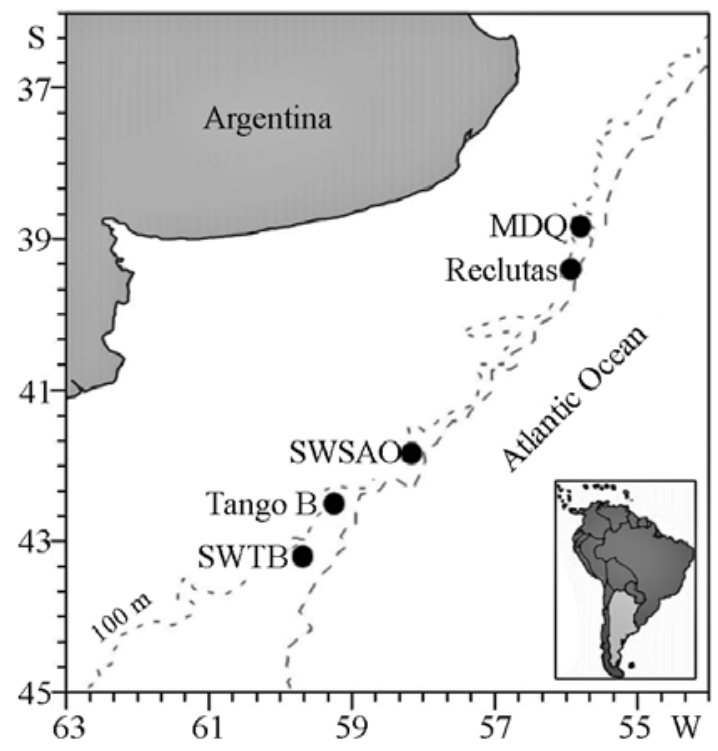

Figure 1

Location of the commercial Patagonian scallop beds MDQ, Reclutas, SWSAO, Tango B and SWTB over the Argentinian Continental Shelf

Ubicación de los bancos comerciales de vieira patagónica MDQ, Reclutas, SWSAO, Tango B y SWTB en la plataforma continental argentina

${ }^{1}$ Waloszek D. 1991. Chlamys patagonica (King \& Broderip, 1832), a long 'neglected' species from the shelf off the Patagonian coast. In: Shumway SE \& PA Sandifer (eds). World Aquaculture Workshops 1: 256-263. The World Aquaculture Society, Baton Rouge.

${ }^{2}$ Lasta M. 1992. Chlamys patagonica: Resultados del Primer Crucero de Pesca Experimental. Mar del Plata, Argentina, p. 13. 


\section{Sampling procedure and data processing}

Data on 575 samples with complete information (almost $60 \%$ of the total) were selected from about 1000 trawl shots carried out by the commercial fleet. Samples (volume $10 \mathrm{~L}$ ) were always taken from the total catch at random. The bycatch species were sorted, counted and wet-weighted on board. Bycatch species were grouped into major taxa and their density (wet weight g $100 \mathrm{~m}^{-2}$ ) was estimated using a gear-specific catch efficiency coefficient of 35\% (Valero 2002).

To summarize and compare the trends of the taxa biomass, principal component analyses (PCA) were carried out with data from five beds: MDQ, Reclutas, SWSAO, Tango B and SWTB. The data were $\log _{10}(\mathrm{x}+1)$ transformed prior to analysis. PCA is based on the correlations matrix. Correlations with an absolute value greater than 0.60 were considered.

The Kruskal-Wallis test was used to compare the mean biomass of bycatch taxa among years in two beds subjected to differential fishing effort during the study period and properly sampled to develop statistical analysis (SWSAO and SWTB beds). When tests were significant $(P \leq 0.05)$, Dunn's pairwise comparison test was used to identify years that were significantly different from the others (Zar 1996). Regression analysis was applied to investigate possible relationships between mean densities $\left[\log _{10}\right.$ (biomass +1$\left.)\right]$ and standardized fishing effort. We used the number of trawls per year and scallopers as fishing effort data. These data come from two different nets of head and foot rope equal to 17 and $22 \mathrm{~m}$ each. The number of trawl per vessel/year/bed was multiplied by a factor that relates these different sizes (net size/largest net size), in order to standardize the fishing effort data.

\section{Results}

In all, eight invertebrate taxa (Anthozoa, Ascidiacea, Brachiopoda, Crustacea, Echinodermata, Gastropoda, Polychaeta and Porifera) were recorded by on-board observers from 1997 to 2002. The total bycatch biomass showed large variations among beds and years; the eight taxa were present in all beds. The estimated mean weight of benthic bycatch varied between 181.19 and $888.57 \mathrm{~g}$ $100 \mathrm{~m}^{-2}$ during the study period (Table 1 ). Excluding single samples (MDQ 2000 and Tango B 2001), the bycatch ranged between $6.20 \%$ and $41.52 \%$ of total catch biomass (Table 2). The lowest percentages of bycatch were registered in the SWTB bed.

PCA analyses were performed for each bed, which showed a great variability in total density during the study period. The first two axes of the PCA explained almost $65 \%$ of the total variation in the MDQ bed, more than $78 \%$ in the Reclutas bed, $72 \%$ in the SWSAO bed, more than $78 \%$ in the Tango B bed and 74\% in the SWTB bed (Fig. 2). In the five beds, the variability was mostly explained by bycatch biomass gradient along axis 1 and by Gastropoda biomass gradient along axis 2 . The five beds showed similar patterns, with bycatch, Echinodermata and Porifera biomass in the same direction and Gastropoda biomass at $c a .90^{\circ}$ angle in relation to Echinodermata biomass, showing no correlation between these two variables. In the MDQ, Tango B and SWTB beds, Echinodermata and Porifera were very closely correlated.

Table 1

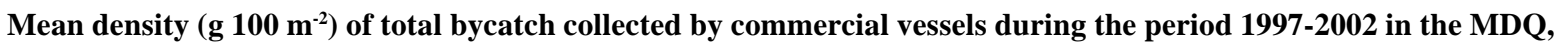
Reclutas, SWSAO, Tango B and SWTB Patagonian scallop beds, Argentine Sea

Densidad promedio (g $100 \mathrm{~m}^{-2}$ ) del total de la captura incidental recolectada por buques comerciales durante el período 1997-2002 en los bancos de vieira patagónica MDQ, Reclutas, SWSAO, Tango B y SWTB, Mar Argentino

\begin{tabular}{ccccccccccc}
\hline & \multicolumn{2}{c}{ MDQ } & \multicolumn{2}{c}{ Reclutas } & \multicolumn{2}{c}{ SWSAO } & \multicolumn{2}{c}{ Tango B } & \multicolumn{2}{c}{ SWTB } \\
& Mean & SD & Mean & SD & Mean & SD & Mean & SD & Mean & SD \\
\hline 1997 & 620.76 & 491.39 & 427.32 & 101.02 & 445.09 & 442.37 & - & - & - & - \\
1998 & - & - & - & - & 480.88 & 293.17 & 387.76 & 251.91 & - & - \\
1999 & 181.69 & 172.27 & - & - & 402.85 & 584.96 & 441.03 & 580.12 & 514.28 & 668.22 \\
2000 & 412.34 & - & 282.32 & 323.57 & 321.39 & 240.53 & - & - & 294.85 & 308.41 \\
2001 & 507.82 & 432.86 & 758.08 & 538.71 & 474.60 & 198.26 & 483.05 & - & 888.57 & 568.04 \\
2002 & 487.35 & 349.90 & 370.68 & 317.86 & 538.05 & 674.58 & 521.11 & 635.69 & 510.92 & 626.34 \\
\hline
\end{tabular}


Table 2

Mean and standard deviation of the percentages of bycatch in the total catch during the period 1997-2002 in the MDQ, Reclutas, SWSAO, Tango B and SWTB Patagonian scallop beds, Argentine Sea

Promedio y desviación estándar de los porcentajes de captura incidental en la captura total durante el período 1997-2002 en los bancos de vieira patagónica MDQ, Reclutas, SWSAO, Tango B y SWTB, Mar Argentino

\begin{tabular}{rcccccccccr}
\hline & \multicolumn{3}{c}{ MDQ } & \multicolumn{2}{c}{ Reclutas } & \multicolumn{2}{c}{ SWSAO } & \multicolumn{2}{c}{ Tango B } & \multicolumn{2}{c}{ SWTB } \\
& Mean & SD & Mean & SD & Mean & SD & Mean & SD & Mean & SD \\
\hline 1997 & 30.83 & 15.88 & 29.63 & 2.12 & 14.24 & 5.35 & - & - & - & - \\
1998 & - & - & - & - & 21.99 & 5.87 & 31.10 & 11.08 & - & - \\
1999 & 34.53 & 2.14 & - & - & 23.88 & 14.12 & 41.52 & 10.25 & 10.66 & 6.46 \\
2000 & 49.1 & - & 27.35 & 11.42 & 38.81 & 14.33 & - & - & 8.96 & 13.25 \\
2001 & 38.53 & 23.55 & 30.45 & 16.69 & 33.09 & 15.64 & 69.04 & - & 6.20 & 5.17 \\
2002 & 26.65 & 21.93 & 32.64 & 15.24 & 24.95 & 21.12 & 35.31 & 21.31 & 9.18 & 10.56 \\
\hline
\end{tabular}
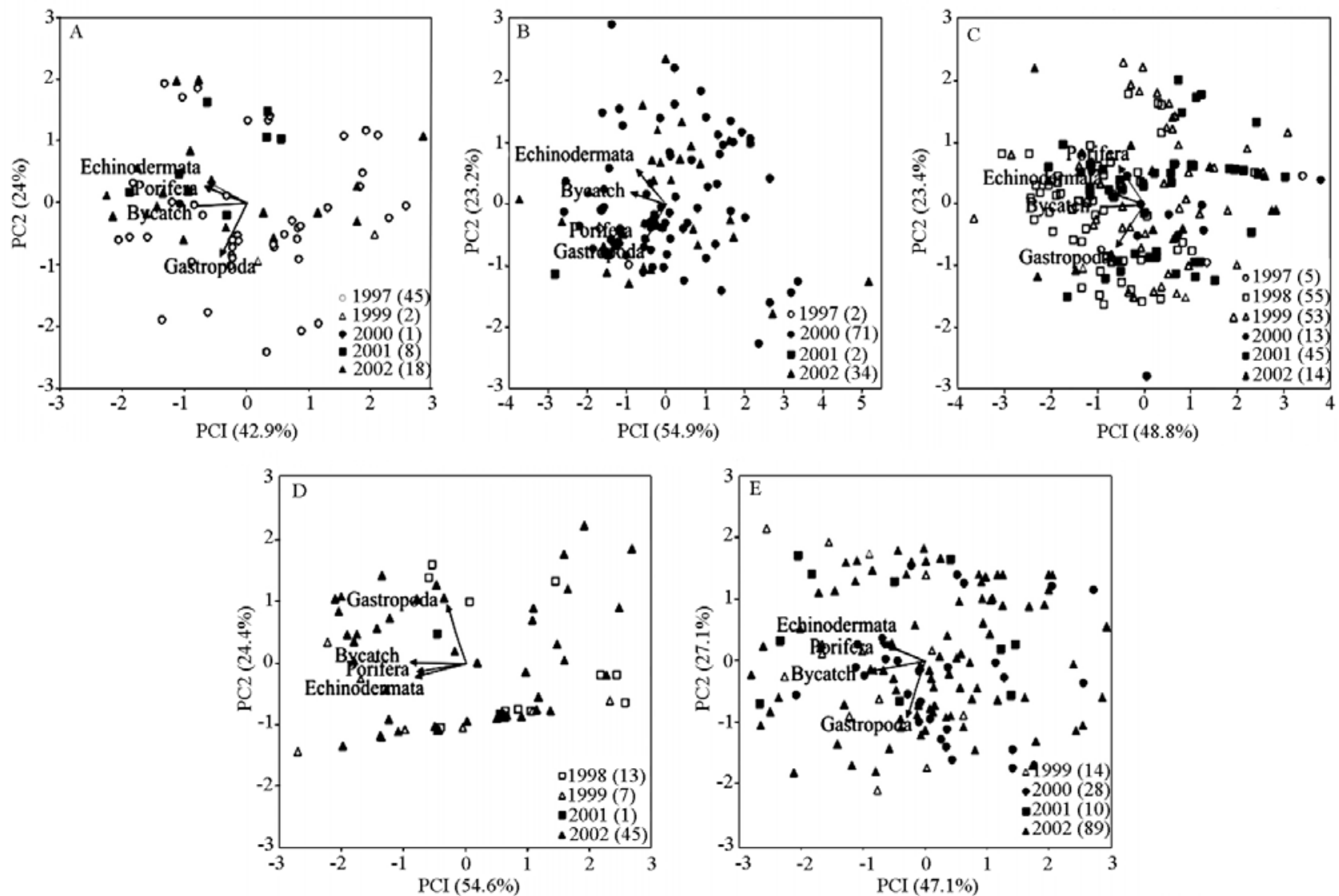

Figure 2

Biplot of the first two principal components with explained variance for the five Patagonian scallop bed analysed. The arrows indicate the directions and rates of change of the biomass taxa. Sample size per year in brackets.

A: MDQ bed; B: Reclutas bed; C: SWSAO bed; D: Tango B bed; E: SWTB bed

Representación de los dos primeros componentes principales con la varianza explicada para los cinco bancos de vieira patagónica analizados. Las flechas indican las direcciones y tasas de cambio de la biomasa de los taxa. Entre paréntesis el tamaño muestral por año. A: banco MDQ; B: banco Reclutas; C: banco SWSAO; D: banco Tango B; E: banco SWTB 
Table 3

Results of pairwise tests on biomass of total bycatch and main taxa, caught during 1997-2002 in the SWSAO and SWTB Patagonian scallop beds, Argentine Sea. Q’, Dunn test; Sign., statistical significance; *, $P<0.05$; **, $P<0.01$; ns, not significant

Resultados de pruebas pareadas sobre la biomasa de la captura incidental total y los principales taxa, capturados durante 1997-2002 en los bancos de vieira patagónica SWSAO y SWTB, Mar Argentino. Q’ prueba Dunn; Sign., significancia estadística;

*, $P<0,05 ; * *, P<0,01$; ns, no significativo

\begin{tabular}{|c|c|c|c|c|c|c|c|c|}
\hline \multicolumn{9}{|l|}{ SWSAO } \\
\hline Gastropoda & Q' & Sign. & Echinodermata & Q' & Sign. & Bycatch & $Q^{\prime}$ & Sign. \\
\hline $1997-1998$ & 8.21 & ** & $1997-1998$ & 4.81 & ** & $1997-1998$ & 8.16 & $* *$ \\
\hline $1997-1999$ & 5.21 & $* *$ & 1997-1999 & 0.57 & ns & $1997-1999$ & 3.27 & * \\
\hline $1997-2000$ & 19.65 & ** & $1997-2000$ & 10.33 & $* *$ & $1997-2000$ & 6.77 & $* *$ \\
\hline $1997-2001$ & 4.51 & ** & $1997-2001$ & 0.33 & ns & $1997-2001$ & 2.88 & ns \\
\hline $1997-2002$ & 8.09 & ** & $1997-2002$ & 8.20 & ** & $1997-2002$ & 18.29 & $* *$ \\
\hline 1998-1999 & 4.29 & ** & 1998-1999 & 7.25 & $* *$ & 1998-1999 & 6.75 & $* *$ \\
\hline $1998-2000$ & 1.93 & ns & $1998-2000$ & 11.19 & ** & $1998-2000$ & 7.79 & $* *$ \\
\hline 1998-2001 & 6.17 & *** & 1998-2001 & 7.11 & ** & $1998-2001$ & 8.02 & $* *$ \\
\hline 1998-2002 & 7.2 & ** & 1998-2002 & 2.53 & ns & 1998-2002 & 2.15 & ns \\
\hline $1999-2000$ & 2.37 & ns & $1999-2000$ & 4.12 & $* *$ & $1999-2000$ & 1.15 & ns \\
\hline 1999-2001 & 1.76 & ns & 1999-2001 & 0.39 & ns & $1999-2001$ & 1.05 & ns \\
\hline 1999-2002 & 2.97 & * & 1999-2002 & 4.87 & ** & 1999-2002 & 4.74 & $* *$ \\
\hline $2000-2001$ & 4.56 & ** & $2000-2001$ & 5.03 & ** & $2000-2001$ & 0.15 & ns \\
\hline $2000-2002$ & 10.30 & ** & 2000-2002 & 17.35 & $* *$ & $2000-2002$ & 11.32 & ** \\
\hline $2001-2002$ & 1.38 & ns & $2001-2002$ & 5 & ${ }^{* *}$ & 2001-2002 & 6.43 & $* *$ \\
\hline \multicolumn{9}{|l|}{ SWTB } \\
\hline Porifera & Q' & Sign. & Bycatch & Q' & Sign. & & & \\
\hline $1999-2000$ & 11.16 & $* *$ & $1999-2000$ & 8.26 & ** & & & \\
\hline 1999-2001 & 9.02 & ** & 1999-2001 & 1.91 & ns & & & \\
\hline 1999-2002 & 4.56 & ** & 1999-2002 & 4.34 & ** & & & \\
\hline $2000-2001$ & 4.50 & ** & 2000-2001 & 9.47 & ** & & & \\
\hline 2000-2002 & 0.77 & ns & 2000-2002 & 0.56 & ns & & & \\
\hline $2001-2002$ & 1.33 & ns & $2001-2002$ & 4.47 & ** & & & \\
\hline
\end{tabular}

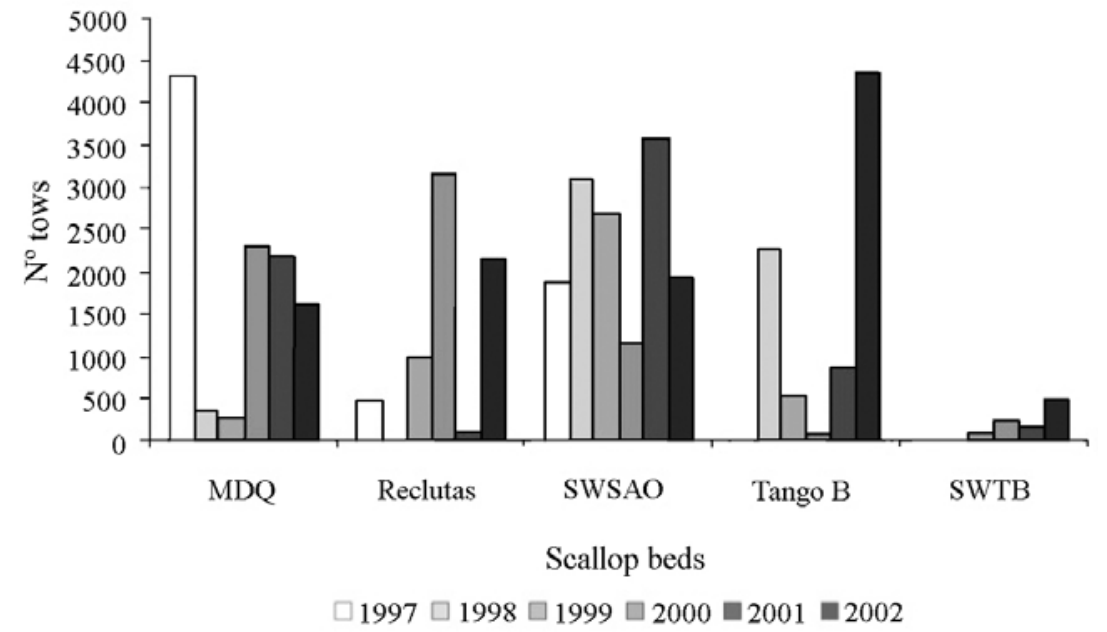

Figure 3

Number of commercial tows in Patagonian scallop beds during the period 1997-2002

Número de lances comerciales en bancos de vieira patagónica durante el período 1997-2002 
Distribution of fishing effort varied between beds during the period 1997-2002 (Fig. 3). The MDQ and SWSAO beds were subjected to the greatest fishing effort, more than 2000 tows during most of the years analysed. The lowest fishing effort during the study period was exerted on the SWTB bed, lower than 500 tows per year.

Kruskal-Wallis tests showed significant differences among years in biomass of bycatch $\left(H^{\prime}=28.87, P<0.01\right)$, Echinodermata $\left(\mathrm{H}^{\prime}=30.64, P<0.01\right)$ and Gastropoda $\left(H^{\prime}=18.99, P=0.002\right)$ in the SWSAO bed. The highest values of bycatch and Echinodermata were found in 1998 and 2002, statistically different from the rest of the years. Gastropoda were best represented in 1998, 1999 and
2000, without statistical differences between those years (Table 3, Fig. 4a). Echinodermata biomass represented more than half of total bycatch in the whole study period, except during 2000. In the SWTB bed, the bycatch (H'= 18.12, $P<0.001)$ and Porifera $\left(H^{\prime}=14.61, P=0.002\right)$ biomass were significantly different among years. Bycatch biomass was higher in 1999 and 2001 and differed from 2000 and 2002. The highest value of Porifera biomass was found in 1999 and differed significantly from other years (Table 3, Fig. 4b).

Regression analyses between mean density of taxa and fishing effort at SWSAO and SWTB beds were not significant (Table 4).
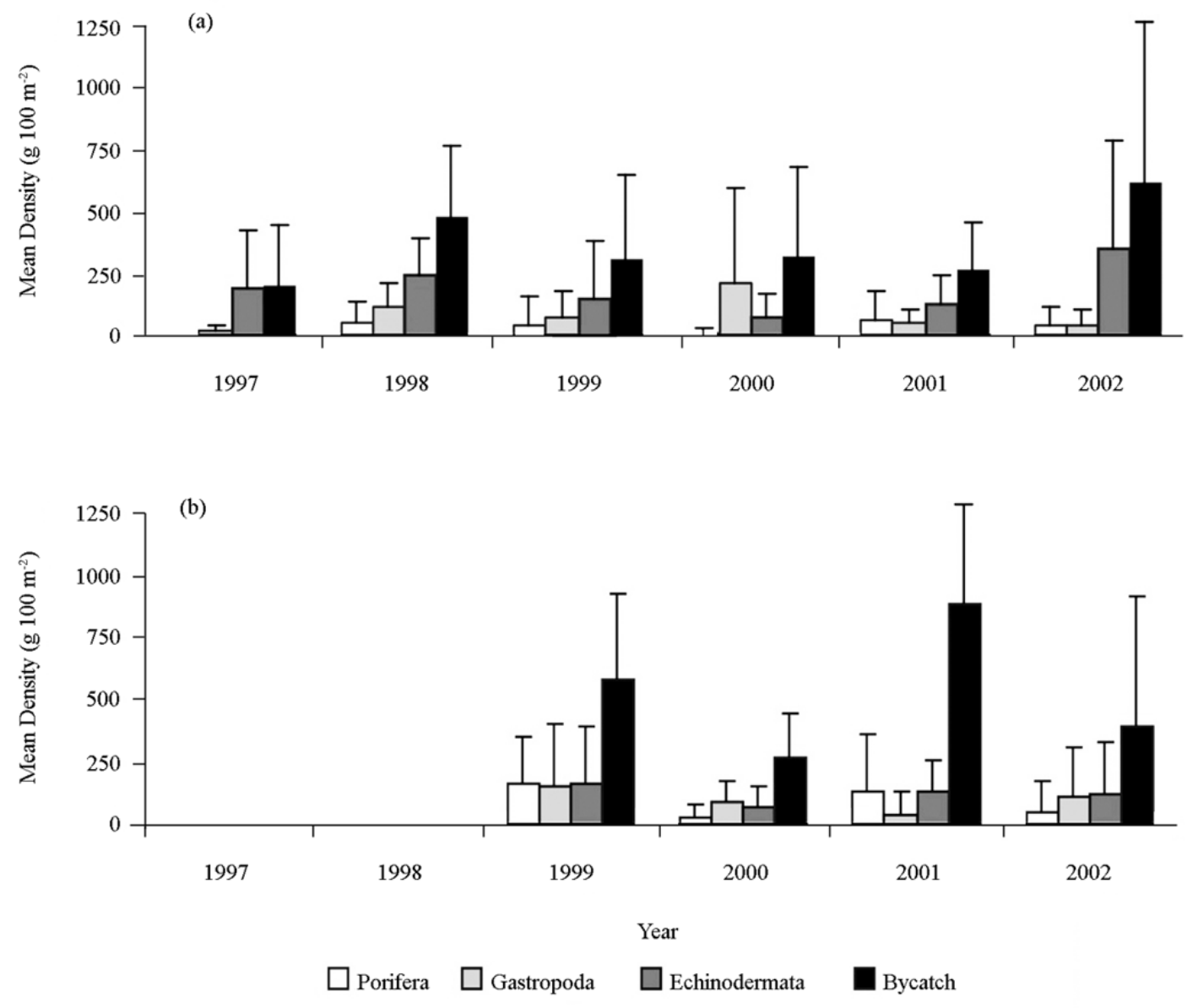

Figure 4

Mean and standard deviation of bycatch biomass in the SWSAO (a) and SWTB (b) Patagonian scallop beds during the study period

Promedio y desviación estándar de la biomasa de captura incidental en los bancos de vieira patagónica SWSAO (a) y SWTB (b) durante el período de estudio 
Table 4

\section{Results of regressions of mean density $\left(\log _{10}\right.$ [biomass +1$\left.]\right)$ of four taxa and fishing effort in the SWSAO and SWTB beds, Argentine Sea. Regression coefficients are shown with $P$ values in brackets}

Resultados de las regresiones entre las densidades media $\left(\log _{10}\right.$ [biomasa+1]) de 4 grupos y esfuerzo pesquero en los bancos SWSAO y SWTB, Mar Argentino. Se muestran los coeficientes de la regresión y valor de $P$ entre paréntesis

\begin{tabular}{lcccc}
\hline & Porifera & Gastropoda & Echinodermata & Bycatch \\
\hline Fishing effort SWSAO & $0.559(0.248)$ & $-0.128(0.808)$ & $0.286(0.5819)$ & $0.079(0.881)$ \\
Fishing effort SWTB & $-0.658(0.341)$ & $0.033(0.966)$ & $-0.359(0.64)$ & $-0.509(0.49)$ \\
\hline
\end{tabular}

\section{Discussion}

This study compiles information about the invertebrate bycatch of the Patagonian scallop fishery using data collected by means of the On-Board Observers Program at INIDEP. Our results showed the presence of eight taxonomic groups during 1997-2002 in all beds. Echinodermata was the dominant taxon in the scallop beds, together with Gastropoda and Porifera. This coincides with previous studies developed with baseline data obtained by experimental cruises in 1995 (Bremec et al. 1998, Bremec \& Lasta 2002). Updated information coming from yearly research surveys also shows the predominance of echinoderms in terms of biomass and that the epibenthic fauna associated with the Patagonian scallop fishery has been persistent during the past ten years (Bremec et al. 2006, Schejter \& Bremec 2007, Schejter et al. 2008).

Large variations in density of these groups of invertebrates and total bycatch were found in relation to beds and years studies. Our analysis did not show variability of bycatch density related with fishing effort. The ordinations of values in our PCA did not show different faunal conditions in different years that could indicate a general response of epifauna to trawling. We found different densities, which represent different percentages of total bycatch, at different levels of fishing effort exerted on the beds. However, the percentage of bycatch collected showed an increase after some years of trawling in every bed, except in the SWTB bed where fishing effort was relatively low. The case of the heavily exploited SWSAO bed gives an example of a condition found after intensive and high fishing effort. The lower mean density of bycatch (321.39 g $100 \mathrm{~m}^{-2}$ ) corresponds to the higher percentage of total catch (39\%) in 2000 (Tables 1 and 2), year that was preceded by a period of intensive activity of the fleet (Fig. 3). This particular situation perhaps could be attributed to some of the shorttime consequences of the fishery, i.e. extraction of target species and damage of non-target ones. Fluctuations in biomass and abundance of bycatch groups have been documented in other regions (Veale et al. 2000, Demestre et al. 2000).

Our study case showed significant differences in density of Echinodermata and Gastropoda in the SWSAO bed and Porifera in the SWTB bed between 1997 and 2002 (Table 3, Fig. 4). The main differences between both beds are notorious. Sessile organisms were recorded more abundantly in the SWTB bed, not exploited until 1999, while this group was scarcely collected in the SWSAO bed, which was exploited since the start of the fishery. On the other hand, Echinodermata and Gastropoda showed similar densities in the SWTB bed and variable ones in the SWSAO bed during the study period. Although we did not find any significant relationship between fishing effort and mean densities of taxa (Table 4), other studies (Schejter et al. 2008) recorded some changes in exploited areas of the Reclutas scallop bed. These authors found an increase in the density of ophiuroids (detritivores) and a decrease of fragile echinoid species, difference that could not be assessed with our data that included Echinoidea, Ophiuroidea and Asteroidea as a single faunal group (Echinodermata). In coincidence, both studies show the increase of this group after intensive fishing effort. In the case of Porifera, the highest biomass was found in 1999 in the SWTB bed, just at the beginning of the fishing activity, followed by a significant decrease. Similar results were obtained by Bremec et al. (2000); they found that sessile taxa decreased in biomass between 1995 (baseline data) and 1998, after years of trawling in a northern bed $\left(39^{\circ} \mathrm{S}\right)$ characterized by the same Patagonian scallop 
assemblage. This change has been well documented in other scallop fishing grounds (Alverson et al. 1994, Collie et al. 1997, Bradshaw et al. 2002).

The consequences of trawling activities on ecosystems have been frequently studied during the past years. Common trends of community responses have been detected, for instance, areas with high disturbance may become more uniform and characterized by fewer and more dominant species. In general, sessile organisms like hydrozoans, bryozoans and sponges decreased and/or disappeared, being more vulnerable to the impact (Kaiser et al. 2000, Bradshaw et al. 2002, Callaway et al. 2007). Scavengers and predators increase due to discards and damaged organisms on the sea floor that provide a large amount of food: echinoderms and gastropods were collected in abundance in scallop fishing grounds and areas subjected to trawling activities (Kaiser \& Spencer 1996, Lindeboom \& de Groot 1998, Rumohr \& Kujawski 2000, Pranovi et al. 2001, Guijarro Garcia et al. 2006). In this context, we stress out the important ecological role of the groups of bycatch herein analysed. Gastropoda species are the main predators of Patagonian scallops, whereas the top predator of the community, an asteroid, preys on gastropods (Botto et al. 2006). Many of the predator species in the Patagonian scallop beds could be favoured by discards and damaged benthos. Regarding sessile organisms, Bremec et al. (2008) showed that hydroid colonies are the primary settlement substrate of scallop spat, due to the filamentous microhabitats (architecture) provided (see Cragg 2006). The hydroids were mainly settled down on sponges, polychaete tubes and scallops, what clearly indicates the functional role of Porifera, taxon very vulnerable to trawling, in these fishing grounds.

Presently, the management strategy is to incorporate an adaptive criteria, following a rotating pattern and shifting the allocation of fishing effort. The OBOP offers the opportunity to monitor the habitat involved in this fishery. This source of data is optimal for producing longterm databases containing spatial and temporal distributions of benthic biomass and fishing effort. Future work should therefore, utilize both observer and scientific community data for the allocation of fishing effort in Patagonian scallop management strategies.

\section{Acknowledgments}

This paper was greatly improved with the suggestions of the reviewers. We acknowledge those observers on board that contributed with their work during the study period. The paper was partially funded by INIDEP (OBOP) and PICT 15080, 1553 and 02200. Glaciar Pesquera S.A. provided a contract to MD. This is INIDEP Contribution No 1547.

\section{Literature cited}

Acha M, H Mianzan, R Guerrero, M Favero \& J Bava. 2004. Marine fronts at the continental shelves of austral South America. Physical and ecological processes. Journal of Marine Systems 44: 83-105.

Alverson DL, MH Freebag, SA Murawski \& JG Pope. 1994. A global assessment of fisheries bycatch and discards. FAO Fisheries Technical Paper 339: 1-233.

Botto F, C Bremec, A Marecos, L Schejter, M Lasta \& O Iribarne. 2006. Identifying predators of the SW Atlantic Patagonian scallop Zygochlamys patagonica using stable isotopes. Fisheries Research 81: 45-50.

Bradshaw C, LO Veale \& AR Brand. 2002. The role of scallop-dredge disturbance in long-term changes in Irish Sea benthic communities: a re-analysis of an historical dataset. Journal of Sea Research 47: 161-184.

Bremec CS \& M Lasta. 2002. Epibenthic assemblage associated with scallop (Zygochlamys patagonica) beds in the Argentinian Shelf. Bulletin of Marine Science 70: 89105.

Bremec CS, M Lasta, L Lucifora \& J Valero. 1998. Análisis de la captura incidental asociada a la pesquería de vieira patagónica Zygochlamys patagonica (King \& Broderip, 1832). Informe Interno, INIDEP 22: 1-18.

Bremec CS, T Brey, M Lasta, J Valero \& L Lucifora. 2000. Zygochlamys patagonica beds on the Argentinian shelf: Part I: energy flow thought the scallop bed community. Archives of Fisheries and Marine Research 48: 295-303.

Bremec CS, L Schejter \& A Marecos. 2006. Riqueza específica y asociaciones faunísticas en los bancos comerciales de vieira patagónica (Zygochlamys patagonica) a lo largo del frente de talud. Período 1995-2006. Informe Interno, INIDEP 106: 1-52.

Bremec CS, M Escolar, L Schejter \& G Genzano. 2008. Primary settlement substrate of scallop, Zygochlamys patagonica (King \& Broderip, 1832) (Mollusca: Pectinidae) in fishing grounds in the Argentine Sea. Journal of Shellfish Research 27: 273-280.

Callaway R, GH Engelhard, J Dann, J Cotter \& H Rumohr. 2007. A century of North Sea epibenthos and trawling: comparison between 1902-1912, 1982-1985 and 2000. Marine Ecology Progress Series 346: 27-43.

Ciocco NF, ML Lasta, M Narvarte, C Bremec, E Bogazzi, J Valero \& JM (Lobo) Orensanz. 2006. Fisheries and aquaculture: Argentina. In: Shumway SE \& GJ Parsons (eds). Scallops: Biology, ecology and aquaculture 2: 12511292. Elsevier, Amsterdam.

Collie JS, GA Escanero \& PC Valentine. 1997. Effects of bottom fishing on the benthic megafauna of Georges Bank. Marine Ecology Progress Series 155: 152-172. 
Cragg S. 2006. Development, physiology, behaviour and ecology of scallop larvae. En: Shumway SE \& GJ Parsons (eds). Scallops: Biology, ecology and aquaculture 2: 45105. Elsevier, Amsterdam.

Demestre M, P Sánchez \& MJ Kaiser. 2000. The behavioural response of benthic scavengers to otter trawling disturbance in the Mediterranean. En: Kaiser MJ \& SJ de Groot (eds). Effects of fishing on non-target species and habitats, pp. 121-129. Blackwell Science, Oxford.

Guijarro García E, SA Ragnarsson \& H Eiríksson. 2006. Effects of scallop dredging on macrobenthic communities in west Iceland. ICES Journal of Marine Science 63: 434443.

Hill AS, LO Veale, D Pennington, SG Whyte, AR Brand \& RG Hartnoll. 1999. Changes in Irish Sea benthos: possible effects of 40 years of dredging. Estuarine, Coastal and Shelf Science 48: 739-750.

Kaiser MJ \& BE Spencer. 1996. Behavioural responses of scavengers to beam trawl disturbance. In: Greenstreet SPR \& ML Tasker (eds). Aquatic predators and their prey, pp. 169-218. Liverpool University Press, Liverpool.

Kaiser MJ, K Ramsay, CA Richardson, FE Spence \& AR Brand. 2000. Chronic fishing disturbance has changed shelf sea benthic community area. Journal of Animal Ecology 69: 494-503.

Lasta M \& C Bremec. 1998. Zygochlamys patagonica in the argentine Sea: A new scallop fishery. Journal of Shellfish Research 17: 103-111.

Lindeboom HJ \& SJ de Groot. 1998. IMPACT II. The effects of different types of fisheries on the North Sea and Irish Sea benthic ecosystems. NIOZ-Rapport 1998-1, RIVODLO Report C003/98: 1-404.
Pranovi F, S Raicevich, G Franceschini, P Torricelli \& O Giovanardi. 2001. Discards analysis and damage to nontarget species in the 'rapido' trawl fishery. Marine Biology 139: 863-875.

Rumohr H \& T Kujawski. 2000. The impact of trawl fishery on the epifauna of the southern North Sea. ICES Journal of Marine Science 57: 1389-1394.

Schejter L \& C Bremec. 2007. Benthic richness in the Argentine continental shelf: the role of Zygochlamys patagonica (Mollusca: Bivalvia: Pectinidae) as settlement substrate. Journal of the Marine Biological Association of the United Kingdom 87: 917-925.

Schejter L, CS Bremec \& D Hernández. 2008. Comparison between disturbed and undisturbed areas of the Patagonian scallop (Zygochlamys patagonica) fishing ground 'Reclutas' in the Argentine Sea. Journal of Sea Research 60: 193-200.

Valero JL. 2002. Analysis of temporal and spatial variation in growth and natural mortality estimation with an integrated dynamic model in the Patagonian Scallop (Zygochlamys patagonica). MSc Thesis, School of Aquatic and Fishery Sciences, University of Washington, Seattle, 154 pp.

Veale LO, AS Hill, SJ Hawkins \& AR Brand. 2000. Effects of long-term physical disturbance by commercial scallop fishing on subtidal epifaunal assemblages and habitats. Marine Biology 137: 325-337.

Zar JH. 1996. Biostatistical analysis, 662 pp. Prentice Hall, Englewood Cliffs.

Recibido el 6 de noviembre de 2008 y aceptado el 24 de abril de 2009 